\title{
Delphinium malabaricum (huth) munz: a potential ornamental crop from Western Ghats
}

\begin{abstract}
Delphinium malabaricum (Huth) Munz. (Ranunculaceae), the only species of the genus Delphinium growing naturally in Western India, is endemic to Northern Western Ghats of Maharashtra. It produces beautiful and attractive spurred flowers of violet blue color with splendid green rosette foliage. Herein, we report our preliminary observations relating to seed germination, growth performance and post harvest performance of cut flowering stems of this plant. The annotations revealed that the seeds germinated throughout the year but the germination percentage was very low in March, April and May when there is high temperature. Plants grown from seeds collected from a wild habitat exhibited variation in their vigor, branching, leaves, flower color and number. Phenological studies showed that the vase life of Delphinium cut flowers is 5-7 days and are very sensitive to ethylene. A combination of sucrose and silver nitrate was determined as the best holding solution for cut Delphinium blooms, as it prevented flower abscission and slightly delayed flower senescence. Selection and breeding efforts are underway to further improve plant growth, flower quality and display life of cut flowering axis.
\end{abstract}

Keywords: delphinium malabaricum, ranunculaceae, endemic, ornamental, western ghats, vase life

\author{
Volume I Issue I - 2017
}

\author{
Firdose R Kolar, Sandeep R Pai, Ghansham B \\ Dixit \\ Laboratory of Cytogenetics and Plant Breeding, Department of \\ Botany, Shivaji University, India
}

Correspondence: Firdose R Kolar, Laboratory of Cytogenetics and Plant Breeding, Department of Botany, Shivaji University, Kolhapur-4I6004 (M.S.) India,Tel +91- 8277284666

E-mail firdose.kousar@gmail.com

Received: April 25, 2017 | Published: September 0I, 2017

\section{Introduction}

The importance of horticulture in improving the productivity of land, generating employment, improving economic conditions of the farmers and entrepreneurs, enhancing exports and above all, providing nutritional security to the people, is widely acknowledged. Commercial floriculture has been of recent origin though the traditional flower cultivation has been going on for centuries. Emphasis has been shifting from traditional flowers to cut flowers for export purposes. The liberalization of economy since 1991-92 has given an impetus to the Indian entrepreneurs for establishing export oriented floriculture unit under controlled climatic conditions. Maharashtra, Karnataka, Andhra Pradesh and Haryana have emerged as major floriculture centers in recent times. At present a large area is under floriculture cultivation with a high production of loose flowers and cut flowers. With the growing competitiveness, floriculture units in India have been facing several constraints and by addressing the problems, the industry is becoming a viable enterprise for earning foreign exchange. Rose, Carnations, Gerberas are some of the exotic cut flowers well established and appreciated worldwide. Larkspur has also emerged as highly appreciated cut flower. Delphinium malabaricum a member of family Ranunculaceae is an Indian relative of horticulturally introduced larkspurs (Delphiniums). Delphinium includes horticulturally important species such as D. ajacis, D. belladonna, $D$. elatum and $D$. grandiflorum with many cultivars showing mostly blue, white or violet flowers.

There are about 370 species of Delphinium L. distributed in the northern temperate regions of the world. ${ }^{2}$ The genus Delphinium is represented by about 24 species in India that are mainly confined to the Himalayan region (Rau 1993). D. denudatum is a widely distributed species found in the Western Himalayas and in Kashmir at altitudes of 2400-3650 m, especially on grassy slopes. ${ }^{3}$ D. malabaricum (Huth) Munz is the only species of the genus found in Western Ghats. It is an endemic, vulnerable, perennial herb with very attractive racemes making it a potential ornamental flowering perennial. Keeping the above view in mind a domestication program of D. malabaricum was attempted, there by conserving the genome of a potential ornamental wild plant of the Western Ghats. In this report we summarize our preliminary results relating to seed germination, growth and post harvest performance of cut flowering stems of D. malabaricum.

\section{Materials and methods}

An extensive field survey to select populations and collect seeds of D.malabaricum was completed from different localities (Ajinkyatara, Yavteshwar, Kartikswami, Kukdeshwar) of Satara, Pune and Thane districts of Maharashtra. Well matured and dried seeds were collected from natural habitat through personal visits, while immature seeds were air dried and stored in air tight stopper plastic jars. Various experiments were performed to evaluate the ornamental potential of these collections and to standardize a preliminary protocol for domestication, as described below.

\section{Seed attributes and germination}

Seed morphological attributes were defined and seed index was determined by measuring the length and breadth of seeds with picometer to millimeter level. Air dried seeds were used for all germination tests and the percentage germination was expressed on the basis of the number of seedlings emerged out of total number of seeds. Protrusion of the radicle through the seed coat was considered as an index of germination. The seeds stored in dry stoppered plastic jars under laboratory conditions were regularly subjected for monthly germination tests in Petri plates and percent germination (on $20^{\text {th }}$ day of a month) was recorded. The seeds were surface sterilized with $0.1 \%$ mercuric chloride $(\mathrm{HgCl} 2)$ for $5 \mathrm{~min}$, washed in distilled water and were plated. Three replicates with 25 seeds each were used and mean values for germination was determined. The temperature and humidity was verified monthly using a digital temperature and humidity meter. 


\section{Growth performance and ornamental potential}

Seeds collected from various localities were sown in experimental plots and pots (Figure 1A \& 1B) at the Department of Botany, Shivaji University, Kolhapur. They were regularly observed for their growth performance and their ornamental potential. Different morphological parameters such as plant height, girth, internodal length, primary and secondary branching as well as number of leaves, scapes, flowers, capsules and seeds per plant and color of flowers were considered for the study. Variations among the flower color in the species were measured with the help of flower color shading chart of the Royal Horticultural Society, London: Flower Council of Holland- Leiden. Height (in $\mathrm{cm}$ ) and number of scapes / plant of 10 randomly selected plants was considered and average height and average number of scapes / plant was determined. Besides, other preliminary parameters such as soil, growing condition, growing season, crop period and vase life of cut flowers were taken in to consideration.

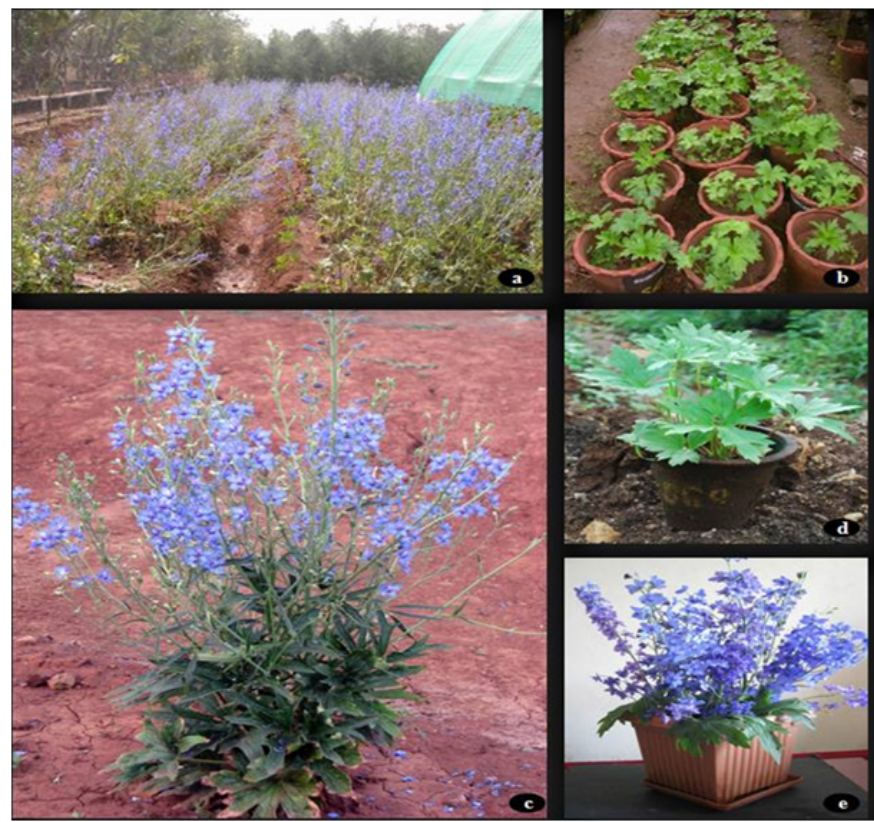

Figure I Delphinium malabaricum (Huth) Munz. (A,B) Cultivation in plots and pots, (C) Habit, (D) Splendid green rosette foliage, (E) Beautiful spikes of Delphinium arranged in a vase.

The vase life of Delphinium malabaricum cut flowers was determined and attempts were also made to improve its post harvest quality. To prolong its vase life, the cut spikes of Delphinium flowers were harvested and placed in conical flasks containing $3 \%, 6 \%$, and $9 \%$ sucrose solutions individually and also in combination with silver nitrate $(0.2 \mathrm{mM}, 0.4 \mathrm{mM} \& 0.6 \mathrm{mM})$ and 8-hydroxyquinoline (100, $200 \& 300 \mathrm{ppm}$ ) and water (no chemical treatment) as control. The flasks were kept in the laboratory at room temperature of $23 \pm 2^{\circ} \mathrm{C}$. Observation on post-harvest parameters was recorded daily, and was monitored in terms of water uptake, change in fresh weight, postharvest color change and analyzed statistically.

\section{Results and discussion}

\section{Seed attributes and germination}

Generally, seed germination is controlled by many internal and external factors. Seed size is one among them. Seed size is an important parameter, which influences the germination, growth and biomass of the seedlings and that trend leads to the future crop yield. The seed traits of Delphinium malabaricum such as, seed length, width, weight and moisture content varied significantly among seed sources. Seed size may vary due to both internal (hereditary) and external (environmental) conditions operating at the time of seed development. ${ }^{4}$ In the case of seed dimensions i.e. seed length and seed breadth, however, very little variation was found. Maximum and minimum seed length was recorded at 1.55 and $2.52 \mathrm{~mm}$, while maximum and minimum seed breadth was recorded at 1.00 and 1.92 $\mathrm{mm}$. The mean 100 -seed weight varied from 0.133 to $0.156 \mathrm{~g}$. The moisture content of air dried seeds varied in the range of 10.0-12.0\% and seed viability was $82 \%$. The percent germination of the seeds was $90-95 \%$ during rainy season, which is the most suitable season for Delphinium propagation.

Seed germination is considered as one of the first and most fundamental life stages of a plant, so that the success in growth and yield production is also dependent on this stage. Seeds are a critical component of the life history of higher plants, providing the main opportunity for a species to disperse to new habitats and escape from adverse conditions in space and time. Germination phenology studies are an effective tool for understanding conditions required for germination and detecting seed dormancy. ${ }^{5}$ The seeds of Delphinium malabaricum were subjected for monthly germination tests to find the optimum germination conditions. The results of these experiments revealed that the relative success of seed germination varied throughout the study period (Table 1). During which it was evident that the seeds were germinating throughout the year, however the percent response varied and the response of seeds during the month of June (93.16\%), July (87.83\%) and August (72.33\%) for germination is more than that seen during October $(23.00 \%)$, November $(57.50 \%)$, December (29.33\%), January (41.16\%) and February (28.60\%). The seed germination response in the month of March (2.50\%), April $(1.50 \%)$ and May $(3.16 \%)$ was very low.

The seeds were found to be very sensitive to high temperature even they showed no germination in the month of March, April and May, when there is increase in temperature and seeds remain dormant until temperatures and moisture are sufficient to cause germination. It seems reasonable to conclude that in delphiniums, good germination rates are likely to be the result of the coincidental provision of the correct temperature and humidity requirements. Different seeds have different temperature ranges within which they germinate. At very low temperature and very high temperatures the germination of all the seeds is prevented. Temperature is an important physical parameter of an environment, which determines the success or failure of a species in a particular condition, which in turns depends mostly on the germ inability of the seed. It is well known that the different population of the same species varies in their temperature and light requirements for germination. Germination requirements of a particular species are a result of the interaction of its genetic makeup with the environment and dormancy pattern of seeds of various plant species, which enable them to survive during adverse conditions. ${ }^{6,7}$ Temperature affects both the capacity for germination, and the rate of germination. When considering temperature effects on germination, dormancy issues may arise. The precise sensitivity is very different according to the species. A rise in temperature does not necessarily cause an increase in either the rate of germination or in its percentage ${ }^{8}$ Delphiniums germinate very well at temperatures between $23^{\circ} \mathrm{C}$ to $25^{\circ} \mathrm{C}$ during the months of June, July and August when the relative humidity is very high. 
Table I Table showing percent seed germination throughout the year in D. malabaricum

\begin{tabular}{llll}
\hline Months & Germination percentage & Temperature $\left({ }^{\circ} \mathrm{C}\right)$ & Relative humidity $(\%)$ \\
\hline Jun & $93.16 \pm 2.04$ & $24.65 \pm 0.22$ & $89.66 \pm 1.51$ \\
Jul & $87.83 \pm 2.76$ & $23.72 \pm 0.10$ & $91.00 \pm 1.24$ \\
Aug & $72.33 \pm 1.73$ & $23.25 \pm 0.13$ & $92.33 \pm 0.18$ \\
Sept & $32.66 \pm 2.45$ & $23.28 \pm 0.04$ & $86.66 \pm 0.13$ \\
Oct & $23.00 \pm 2.44$ & $25.11 \pm 0.25$ & $82.72 \pm 0.98$ \\
Nov & $57.50 \pm 2.58$ & $23.88 \pm 0.29$ & $67.07 \pm 1.18$ \\
Dec & $29.33 \pm 2.83$ & $21.63 \pm 0.24$ & $60.96 \pm 0.72$ \\
Jan & $41.16 \pm 3.23$ & $22.62 \pm 0.22$ & $61.33 \pm 0.67$ \\
Feb & $28.60 \pm 2.34$ & $24.24 \pm 0.17$ & $56.76 \pm 0.12$ \\
Mar & $2.50 \pm 0.92$ & $27.12 \pm 0.12$ & $55.31 \pm 0.45$ \\
Apr & $1.50 \pm 0.72$ & $28.48 \pm 0.34$ & $64.33 \pm 0.59$ \\
May & $3.16 \pm 0.79$ & $28.59 \pm 0.03$ & $69.02 \pm 0.98$ \\
\hline
\end{tabular}

\section{Growth performance and ornamental potential}

Plant growth analysis is considered to be a standard approach to study plant growth and productivity of plant. ${ }^{9}$ Growth and yield are functions of a large number of metabolic processes, which are affected by environmental and genetic factors. Studies of growth pattern and its understanding not only shows how plant grows, but also reveals the events which can make a plant more or less productive. ${ }^{10}$ In the present study growth of the Delphinium malabaricum under field condition was observed and the parameters studied were presented in Table 2. Delphinium malabaricum is a perennial herb (Figure 1C) and requires a deep, well-drained fertile soil and sunny to semi shaded situation for optimal growth. It is very sensitive to short periods of water logging which reduces its growth. The roots were woody cylindrical rhizomatous and black in color. The stem of the plant was selender, glabrous to retrorse pubescent below, pale to bright yellow strigose in inflorescence. The nodes usually beared primary branches from which secondary branches, leaves and flowers developed. The average height of the experimental plants were found to be 98-123 $\mathrm{cm}$. Leaves were petiolated, reniform, 5-6 lobed, petioles sheathed at base. Variations in leaf shapes were also observed. The number of leaves varies from 18-34 per plant.

Table 2 Growth performance of D. malabaricum

\begin{tabular}{lll}
\hline Plant attributes & Average data \pm SE & Range \\
\hline Height of the plant (cms.) & $101.35 \pm 3.80$ & $98-123$ \\
Stem girth (cms.) & $1.43 \pm 0.047$ & $1-1.9$ \\
Primary branches per plant & $6.75 \pm 0.23$ & $5-9$ \\
Secondary branches per plant & $11.15 \pm 1.13$ & $6-27$ \\
Internodal length (cms.) & $3.40 \pm 0.11$ & $2.5-5.3$ \\
Leaves per plant & $19.95 \pm 0.73$ & $18-34$ \\
Scapes per plant & $15.20 \pm 0.64$ & $5-19$ \\
Flowers per axillary scape & $14.78 \pm 0.62$ & $11-23$ \\
Flowers per lateral scape & $9.30 \pm 0.32$ & $5-13$ \\
Capsules per plant & $29.3 \pm 1.20$ & $19-44$ \\
Seeds per capsule & $32.2 \pm 1.03$ & $26-38$ \\
I00 seed Wt. in gms. & $0.146 \pm 0.12$ & $0.133-0.156$ \\
Seed yield per plant (gms.) & $5182.5 \pm 2.15$ & $1920-10240$ \\
Pollen fertility (\%) & $88.73 \pm 0.98$ & $69.9-96.8$ \\
\hline
\end{tabular}


The plant commenced flowering from the last week of September with the appearance of buds, and full blooming occurred by the last week of November. Flowering continued until the end of December. The duration from flower-bud initiation to full bloom is $25-35$ days. The inflorescence consisted of 1-few, rather densely several flowered recemes. The number of flowers per axillary and lateral scape varied from 11-23 and 5-13 respectively. Flowers were bisexual, irregular and blue in color. Flower color variations like light blue, dark blue to purple were also observed, while white flowers were rarely recorded. Stamens were 6-7 mm long, ciliate; anthers bluish and rounded. The Ovaries contained one to many ovules. The follicles were strigulose or glabrous and divergent. The immature capsule was green, and was light yellow to brown in color when matured which contains 2638 numbers of seeds/capsule. Seeds were brown in color, papillose scaly covering or rugulose and without scaly covering. Delphinium is mainly propogated from seed though rhizome is also used. The best season for raising the plant was the rainy season (June-July) when the climate is humid. Delphinium malabaricum produces very beautiful and attractive spurred flowers and splendid green rosette foliage (Figure 1C \& 1D) making it a potential ornamental flowering perennial. The color and shape of the flower and the inflorescence can be appreciated specially when located in a vase (Figure 1E). The attractive beauty of $D$. malabaricum inflorescence encouraged us to characterize its vase value. The phenological studies demonstrated that cut Delphinium flowers have a vase life of 5-7 day. In post harvest trials observations for determining its vase life were made from the development of flower till the senescence, the floral development progresses through 12 stages, with the early stages (stages1-8) characterized by an increase in flower size and change in flower shape as sepals expand, the development of blue pigmentation, and loss of starch Figure 2. The subsequent senescence stages (stages 9-12, Figure 3) are characterized by a reduction of fresh and dry weight, loss of pigment (carotenoids), then wilting and necrosis of the sepals.

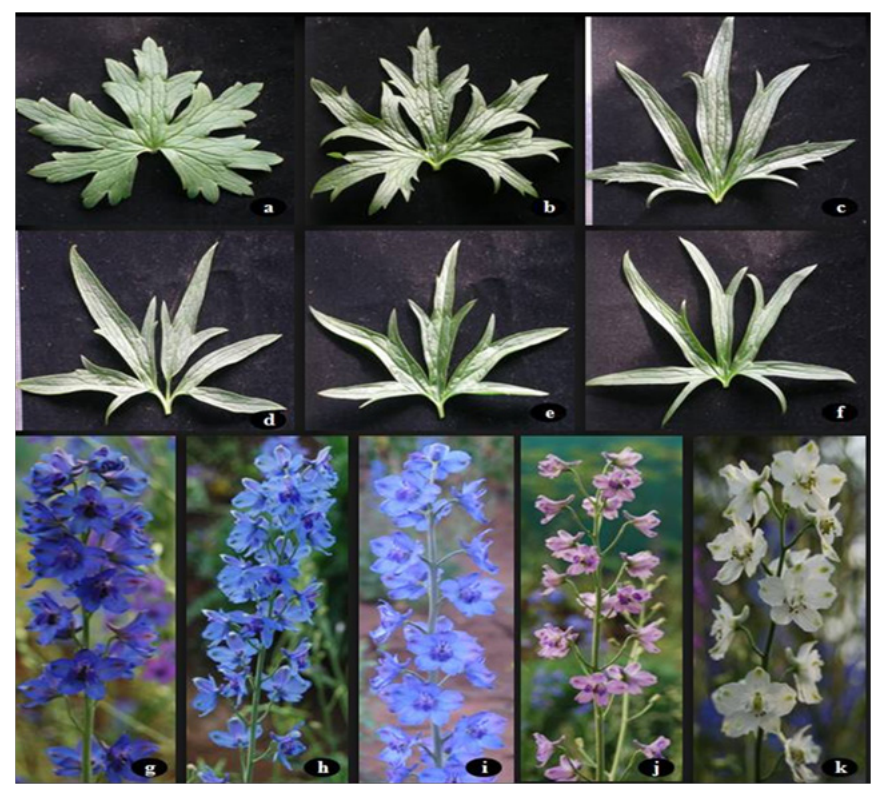

Figure 2 Morphological variations in Delphinium malabaricum (Huth)Munz. a-f: Variation in Leaf shapes; $g-k$ :Variations in flower color.

The short vase life of many cut flowers continues to pose a challenge to the florist industry in general. Flowers are extremely perishable; maintaining their physiological functions very actively even after harvest, and the beginning of their senescence very often depends on ethylene. ${ }^{11}$ Delphinium flowers are very sensitive to ethylene; their sepals rapidly abscise upon exposure to it. ${ }^{12}$ Vase life of cut flowers can be improved by delaying senescence using ethylene synthesis and receptor inhibitors. The use of preservative solution is considered a common practice for the storage of floral stems. These treatments allow to control ethylene synthesis, pathogen development, maintenance of hydric and respiration balance, to contribute to color conservation, floral buttons induction and latter to complete their development. ${ }^{13,14}$ For these reasons, many floral preservative contain germicides, ethylene synthesis inhibitors, growth regulators, some mineral compounds, and carbohydrates that are essential to extend the vase life of cut flowers. ${ }^{14}$

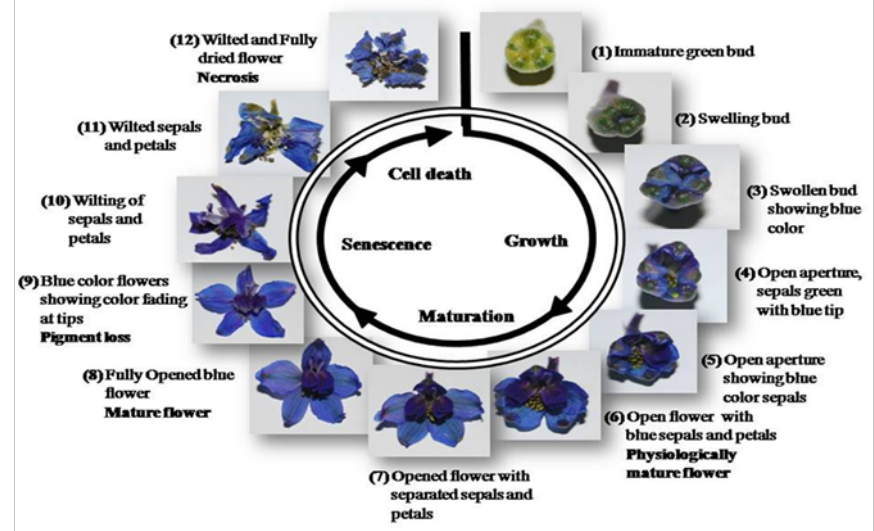

Figure 3 Delphinium malabaricum flower development (Stages I-8) and senescence (Stages 9-12).

In the present study several treatments have been tested for their ability to improve cut flowers opening and vase life, the results of the studies illustrated that the treatment with sucrose in combination with 8-hydroxyquinoline (8-HQ) and silver nitrate $\left(\mathrm{AgNO}_{3}\right)$ extended the vase life of cut Delphinium flowers and inhibited flower senescence (Table 3). All combinations of 8- HQ (100, 200 and 300 ppm) with sucrose $\left(3,6\right.$ and 9\%) showed only intermediate effects, but $\mathrm{AgNO}_{3}$ $(0.2,0.4$ and $0.6 \mathrm{mM})$ with sucrose was observed to be most suitable and effective broad spectrum bactericide as also observed by Nowak $\mathrm{J}^{15}$ in snapdragon. Inclusion of sucrose also failed to significantly extend the vase life of cut flowers, probably due to enhanced microbial growth in the sucrose solution, which ultimately restricted the solution uptake and caused water and sugar stress in the cut spikes. The results revealed that the best holding solution for cut Delphinium blooms would be a combination of silver nitrate and sucrose. The vase-life was prolonged by about 4-5 days by holding the flowers in solution containing $0.4 \mathrm{mM} \mathrm{AgNO}+6 \%$ sucrose as this treatment recorded the maximum useful vase life. Treatment of sucrose in combination with bactericides is markedly very effective in extending the vase life of many cut flowers, as sugars play an important role in plants as substrates for respiration and cell walls as well as osmolytes. Since the amount of sugar contained in cut flowers is limited, the addition of sugars such as sucrose to vase water is effective in promoting bud opening and extending vase life of many cut flowers such as the carnation, rose, ${ }^{17}$ gladiolus, ${ }^{18}$ snapdragon ${ }^{19}$ and sweet pea ${ }^{20-23}$ by inhibiting ethylene production. These results suggest that ethylene production or sensitivity to ethylene may be related to the internal carbohydrate levels. 
Table 3 Effect of floral preservatives on the vase life of D. malabaricum cut flowers

\begin{tabular}{|c|c|c|c|c|}
\hline Treatment & $\begin{array}{l}\text { Fresh weight (g) } \\
\text { (Initial) g }\end{array}$ & $\begin{array}{l}\text { Dry weight (g) } \\
\text { After abscission (Final) g }\end{array}$ & $\begin{array}{l}\text { Ratio } \\
\text { (FW/DW) }\end{array}$ & $\begin{array}{l}\text { Vase life } \\
\text { (Day) }\end{array}$ \\
\hline Control (distilled water) & $2.86 \pm 0.05$ & $1.79 \pm 0.06$ & 1.59 & $6.25 \pm 0.51$ \\
\hline $3 \%$ Sucrose & $2.65 \pm 0.16$ & $1.70 \pm 0.23$ & 1.56 & $8.12 \pm 0.37$ \\
\hline $6 \%$ Sucrose & $2.75 \pm 0.38$ & $2.21 \pm 0.17$ & 1.24 & $8.50 \pm 0.30$ \\
\hline $9 \%$ Sucrose & $3.06 \pm 0.04$ & $2.29 \pm 0.13$ & 1.33 & $9.25 \pm 0.5 \mathrm{I}$ \\
\hline $0.2 \mathrm{mM} \mathrm{AgNO}_{3}$ & $2.19 \pm 0.08$ & $1.65 \pm 0.21$ & 1.32 & $8.50 \pm 0.28$ \\
\hline $0.4 \mathrm{mM} \mathrm{AgNO}_{3}$ & $2.09 \pm 0.06$ & $1.34 \pm 0.06$ & 1.55 & $5.37 \pm 0.81$ \\
\hline $0.6 \mathrm{mM} \mathrm{AgNO}_{3}$ & $1.67 \pm 0.25$ & $0.92 \pm 0.03$ & 1.81 & $5.75 \pm 0.85$ \\
\hline 100ppm 8-HQ & $1.5 I \pm 0.33$ & $0.77 \pm 0.01$ & 1.96 & $8.25 \pm 0.40$ \\
\hline 200ppm 8-HQ & $1.65 \pm 0.47$ & $0.99 \pm 0.02$ & 1.66 & $8.87 \pm 0.93$ \\
\hline 300ppm 8-HQ & $2.96 \pm 0.07$ & $1.58 \pm 0.15$ & 1.87 & $7.25 \pm 0.34$ \\
\hline $0.2 \mathrm{mM} \mathrm{AgNO}_{3}+3 \%$ Sucrose & $1.90 \pm 0.39$ & $1.26 \pm 0.40$ & 1.51 & $9.87 \pm 0.84$ \\
\hline $0.2 \mathrm{mM} \mathrm{AgNO}_{3}+6 \%$ Sucrose & $2.85 \pm 0.08$ & $1.72 \pm 0.32$ & 1.65 & $7.62 \pm 0.29$ \\
\hline $0.2 \mathrm{mM} \mathrm{AgNO}_{3}+9 \%$ Sucrose & $2.52 \pm 0.22$ & $I .7 I \pm 0.27$ & $\mathrm{I} .47$ & $8.75 \pm 0.40$ \\
\hline $0.4 \mathrm{mM} \mathrm{AgNO}_{3}+3 \%$ Sucrose & $2.16 \pm 0.19$ & $\mathrm{I} .47 \pm 0.20$ & 1.46 & $1 \mathrm{l} .37 \pm 0.42$ \\
\hline $0.4 \mathrm{mM} \mathrm{AgNO}_{3}+6 \%$ Sucrose & $2.45 \pm 0.18$ & $1.91 \pm 0.06$ & 1.28 & $12.25 \pm 0.40$ \\
\hline $0.4 \mathrm{mM} \mathrm{AgNO}_{3}+9 \%$ Sucrose & $2.64 \pm 0.34$ & $1.78 \pm 0.45$ & $\mathrm{I} .48$ & $10.12 \pm 0.37$ \\
\hline $0.6 \mathrm{mM} \mathrm{AgNO}_{3}+3 \%$ Sucrose & $2.03 \pm 0.45$ & $|.3| \pm 0.3 \mid$ & 1.54 & $10.50 \pm 0.53$ \\
\hline $0.6 \mathrm{mM} \mathrm{AgNO}_{3}+6 \%$ Sucrose & $1.92 \pm 0.25$ & $1.27 \pm 0.27$ & $|.5|$ & $9.75 \pm 0.51$ \\
\hline $0.6 \mathrm{mM} \mathrm{AgNO}_{3}+9 \%$ Sucrose & $2.5 I \pm 0.07$ & $1.78 \pm 0.09$ & 1.4 & $9.25 \pm 0.40$ \\
\hline 100ppm 8-HQ+3\% Sucrose & $2.28 \pm 0.16$ & $1.53 \pm 0.26$ & 1.48 & $8.25 \pm 0.26$ \\
\hline I00ppm 8-HQ+6\% Sucrose & $1.96 \pm 0.08$ & $1.26 \pm 0.24$ & 1.55 & $8.37 \pm 0.52$ \\
\hline 100ppm 8-HQ+9\% Sucrose & $2.70 \pm 0.21$ & $1.74 \pm 0.28$ & 1.55 & $8.20 \pm 0.48$ \\
\hline 200ppm 8-HQ+3\% Sucrose & $2.63 \pm 0.39$ & $1.85 \pm 0.42$ & 1.42 & $8.62 \pm 0.61$ \\
\hline 200ppm 8-HQ+6\% Sucrose & $1.73 \pm 0.30$ & $1.05 \pm 0.17$ & 1.65 & $8.25 \pm 0.40$ \\
\hline 200ppm 8-HQ+9\% Sucrose & $2.46 \pm 0.39$ & $1.66 \pm 0.30$ & $\mathrm{I} .47$ & $9.62 \pm 0.81$ \\
\hline 300ppm 8-HQ+3\% Sucrose & $2.30 \pm 0.43$ & $1.36 \pm 0.62$ & 1.68 & $8.25 \pm 0.40$ \\
\hline 300ppm 8-HQ+6\% Sucrose & $2.1 I \pm 0.40$ & $1.56 \pm 0.49$ & 1.34 & $9.12 \pm 0.84$ \\
\hline 300ppm 8-HQ+9\% Sucrose & $2.4 I \pm 0.86$ & $1.67 \pm 0.50$ & $\mathrm{I} .44$ & $9.75 \pm 0.74$ \\
\hline
\end{tabular}

Values represent mean $\pm \mathrm{SE}$ of triplicate measurements.

\section{Conclusion}

Delphinium malabaricum grown from seeds collected from a wild population exhibited variation in their vigor, branching, leaves, flower color and number. These differences could be attributed to progressive change in evolution of the species. The presented aesthetic value of unexplored species, may offer the communities additional income and to the buyers an aesthetic satisfaction. Therefore, selection and breeding efforts are necessary to further improve growth characteristics including flower quality and extended display life of cut flowers.

\section{Acknowledgements}

Authors are grateful to the Head, Department of Botany, Shivaji
University, Kolhapur for providing research facilities and also thankful to University Grant Commision, New Delhi for financial assistance.

\section{Conflict of interest}

The author declares no conflict of interest.

\section{References}

1. Katoh N, Tokuhiro K, Nakabayashi T, et al. Breeding of Red-flowering Delphiniums using Inter specific Hybrids Produced by in Vitro Germination. Breeding Science. 2004;54(2):99-103.

2. Blanché C. Revisió biosistemàtica del gènere Delphinium L. al a Península Ibèrica i a les Illes Balears. In: Institut d'Estudis Catalans, la Universidad de California, USA; 1991. p. 1-288. 
3. Bhatnagar SS. The Wealth of India. CSIR: New Delhi, India; 1952. p. $1-30$.

4. Harper JL, Lovell PH, Moore KG. The shapes and sizes of seeds. Annu Rev Ecol Syst. 1970;1:327-356.

5. Baskin CC, Baskin JM. Seeds: Ecology, Biogeography, and Evolution of Dormancy and Germination. USA: Academic Press; 1998. p. 1-666.

6. Wittington WJ. Genetic regulation of germination. In: W Heydecker, editor. Seed Ecology. Proc Nineteenth Ester School in Agric Sci, Butterworth, UK; 1973. p. 5-30.

7. Nikolaeva MG. Factors controlling the seed dormancy pattern. In: The Physiology and Biochemistry of Seed Dormancy and germination. (Ed Khan AA), Elsevier, USA; 1977. p. 1-5174.

8. Mayer AM, Poljakoff Mayber A. The germination of seeds. 2nd ed Pergamon, Oxford, UK; 1975.

9. Wilson WJ. Analysis of growth, photosynthesis and light interception for single plant stand. Ann of Bot. 1981;48(4):507-512.

10. Ahad MA. Growth analysis of Rice bean (Vigna umbellata Thunb.) under different management practices and their agronomic appraisal. USA; 1986. p. 21-22.

11. Figueroa I, Colinas MT, Mejía J, et al. Postharvest physiological changes in roses of different vase life. Ciencia e Investigation Agraria. 2005;32(3):167-176

12. Woltering EJ, van Doorn WG. Role of ethylene in senescence of petals morphological and taxonomical relationships. $J$ Exp Bot. 1988;39(208):1605-1616.

13. Arboleda JA. Principios fundamentales de la postcosecha de flores. En: Tercer Seminario Técnico de Floricul. 1993;93:11-14.
14. Halevy AH, Mayak S. Senescence and postharvest physiology of cut flowers, Part 2. Horticultural Reviews. 1981;3:59-143.

15. Nowak J. Chemical pre-treatment of snapdragon spikes to increase cutflower longevity. Sci Hort. 1981;15:255-262.

16. Dilley DR, Carpenter WJ. The role of chemical adjuvants and ethylene synthesis on cut flower longevity. Acta Hortic. 1975;41:117-132.

17. Kuiper S, Ribot HS, Van Reenen, et al. The effect of sucrose on the flower bud opening of Medelon cut roses. Sci Hortic. 1995;60:325-336.

18. Mayak SB, Braydo, Gvilli A, et al. Improvement of opening of cut gladioli flowers by pretreatment with high sugar concentrations. Sci Hortic. 1973;1:357-365.

19. Ichimura K, Hisamatsu T. Effects of continuous treatment with sucrose on the vase life, soluble carbohydrate concentrations, and ethylene production of cut snapdragon flowers. J Jpn Soc Hortic Sci. 1999;68(1):61-66

20. Ichimura K, Hiraya T. Effect of silver thiosulfate complex (STS) in combination with sucrose on the vase life of cut sweet pea flowers. JJpn Soc Hortic Sci. 1999;68(1):23-27.

21. Ichimura K, Suto K. Effects of the time of sucrose treatment on vase life, soluble carbohydrate concentrations and ethylene production in cut sweet pea flowers. Plant Growth Regul. 1999;28(2):117-122.

22. Arboleda JA. Principios fundamentales de la postcosecha de flores. En: Tercer Seminario Técnico de Floricul. 1993;93:11-14.

23. Harper JL, Lovell PH, Moore KG. The shapes and sizes of seeds. Annu Rev Ecol Syst. 1970;1:327-356. 